\title{
Front Matter: Volume 9378
}

, "Front Matter: Volume 9378," Proc. SPIE 9378, Slow Light, Fast Light, and Opto-Atomic Precision Metrology VIII, 937801 (23 April 2015); doi: 10.1117/12.2192721

SPIE. Event: SPIE OPTO, 2015, San Francisco, California, United States 


\title{
PROCEEDINGS OF SPIE
}

\section{Slow Light, Fast Light, and Opto-Atomic Precision Metrology VIII}

\author{
Selim M. Shahriar \\ Jacob Schever \\ Editors
}

8-12 February 2015
San Francisco, California, United States

Sponsored and Published by

SPIE 
The papers included in this volume were part of the technical conference cited on the cover and title page. Papers were selected and subject to review by the editors and conference program committee. Some conference presentations may not be available for publication. The papers published in these proceedings reflect the work and thoughts of the authors and are published herein as submitted. The publisher is not responsible for the validity of the information or for any outcomes resulting from reliance thereon.

Please use the following format to cite material from this book:

Author(s), "Title of Paper," in Slow Light, Fast Light, and Opto-Atomic Precision Metrology VIII, edited by Selim M. Shahriar, Jacob Schever, Proceedings of SPIE Vol. 9378 (SPIE, Bellingham, WA, 2015) Article CID Number.

ISSN: 0277-786X

ISBN: 9781628414684

Published by

SPIE

P.O. Box 10, Bellingham, Washington 98227-0010 USA

Telephone +1 3606763290 (Pacific Time) · Fax +1 3606471445

SPIE.org

Copyright (@ 2015, Society of Photo-Optical Instrumentation Engineers.

Copying of material in this book for internal or personal use, or for the internal or personal use of specific clients, beyond the fair use provisions granted by the U.S. Copyright Law is authorized by SPIE subject to payment of copying fees. The Transactional Reporting Service base fee for this volume is $\$ 18.00$ per article (or portion thereof), which should be paid directly to the Copyright Clearance Center (CCC), 222 Rosewood Drive, Danvers, MA 01923. Payment may also be made electronically through CCC Online at copyright.com. Other copying for republication, resale, advertising or promotion, or any form of systematic or multiple reproduction of any material in this book is prohibited except with permission in writing from the publisher. The CCC fee code is 0277-786X/15/\$18.00.

Printed in the United States of America.

Publication of record for individual papers is online in the SPIE Digital Library.

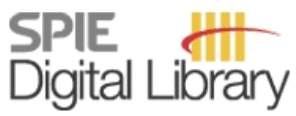

SPIEDigitalLibrary.org

Paper Numbering: Proceedings of SPIE follow an e-First publication model, with papers published first online and then in print. Papers are published as they are submitted and meet publication criteria. A unique citation identifier (CID) number is assigned to each article at the time of the first publication. Utilization of CIDs allows articles to be fully citable as soon as they are published online, and connects the same identifier to all online, print, and electronic versions of the publication. SPIE uses a six-digit CID article numbering system in which:

- The first four digits correspond to the SPIE volume number.

- The last two digits indicate publication order within the volume using a Base 36 numbering

system employing both numerals and letters. These two-number sets start with 00, 01, 02, 03, 04, $05,06,07,08,09,0 A, 0 B \ldots$. OZ, followed by 10-1Z, 20-2Z, etc.

The CID Number appears on each page of the manuscript. The complete citation is used on the first page, and an abbreviated version on subsequent pages. 


\title{
Contents
}

\author{
$\checkmark$ Authors \\ vii Conference Committee
}

SLOW LIGHT: WAVEGUIDES AND RESONATORS

937803 Recent progress in waveguide-based atom photonics (Invited Paper) [9378-2]

PRECISION METROLOGY: CPT-BASED CLOCKS AND COOLED MOLECULAR IONS

$93780 \mathrm{~A} \quad$ Atomic clock based on a coherent population trapping resonance in ${ }^{87} \mathrm{Rb}$ with improved high-frequency modulation parameters (Invited Paper) [9378-9]

SLOW LIGHT: OPTIMIZATION AND APPLICATION OF DELAY

9378 OD Slow light in ruby: delaying energy beyond the input pulse [9378-12]

$9378 \mathrm{OE} \quad$ Strong slow-light resonances in apodized deuterium-loaded femtosecond fiber Bragg gratings (Invited Paper) [9378-13]

FAST LIGHT: GENERATION, APPLICATION, AND COMPARISON WITH SLOW LIGHT

9378 OG Wideband perfect coherent absorber based on white light cavity [9378-15]

$9378 \mathrm{OH} \quad$ Proof of principle experiment on minimizing propagation time in optical communications [9378-16]

$93780 \mathrm{~J} \quad$ Towards long-distance superluminal propagation in optical fibers via cascaded Brillouin lasing resonators (Invited Paper) [9378-18]

PRECISION METROLOGY USING FAST LIGHT: GYROSCOPY AND GRAVITATIONAL WAVE DETECTION

937800 The linewidth of super and sub-luminal lasers (Invited Paper) [9378-23]

SLOW LIGHT: QUANTUM INFORMATION

9378 OR Enhanced wavelength conversion and photon pair generation using slow light effects and electronic carrier sweep out in silicon photonics devices (Invited Paper) [9378-25] 
9378 ОT Measuring the propagation of information and entanglement in dispersive media (Invited Paper) [9378-27]

\section{SLOW LIGHT: NOVEL EFFECTS AND NEW DIRECTIONS}

9378 1B Slow light and narrow resonances in electromagnetic-induced deflection (Invited Paper) [9378-44]

9378 1C Formation of dark states of atoms near metallic nanoparticles (Invited Paper) [9378-45]

PRECISION METROLOGY: COUPLED RESONATOR GYROSCOPES AND OTHER SENSORS

9378 IP Rotation sensitivity analysis of a two-dimensional array of coupled resonators (Invited Paper) [9378-58]

9378 1Q Optimization of gyroscope properties with active coupled resonator optical waveguide structures (Invited Paper) [9378-59]

9378 is Phase modulation detection with liquid crystal devices (Invited Paper) [9378-61]

$93781 \mathrm{~T} \quad$ Nonlinear holography for acoustic wave detection (Invited Paper) [9378-62]

PRECISION METROLOGY: ATOMIC INTERFEROMETRY

9378 IY Atom interferometry using Bose-Einstein condensates on Earth and in space (Invited Paper) [9378-66]

9378 1Z Magnetically guided cold atom gyroscopes and their photonic requirements (Invited Paper) [9378-67]

PRECISION METROLOGY: OPTICAL CLOCK AND FREQUENCY COMBS

937822 Fiber-laser frequency combs for the generation of tunable single-frequency laser lines, mm- and THz-waves and sinc-shaped Nyquist pulses (Invited Paper) [9378-70]

937823 Cascaded optical link on a telecommunication fiber network for ultra-stable frequency dissemination (Invited Paper) [9378-71] 


\title{
Authors
}

Numbers in the index correspond to the last two digits of the six-digit citation identifier (CID) article numbering system used in Proceedings of SPIE. The first four digits reflect the volume number. Base 36 numbering is employed for the last two digits and indicates the order of articles within the volume. Numbers start with 00, 01, 02, 03, 04, 05, 06, 07, 08, 09, 0A, OB...0Z, followed by 10-1Z, 20-2Z, etc.

\author{
Amy-Klein, Anne, 23 \\ Arora, Arushi, OE \\ Bercy, Anthony, 23 \\ Bernier, Martin, $\mathrm{OE}$ \\ Bi, Zhuanfang, $1 Q$ \\ Black, Jennifer A., 03 \\ Bortolozzo, U., 1S, $1 T$ \\ Boyd, Robert W., OD \\ Burke, John H., 1 Z \\ Cavalieri, Stefano, $\mathrm{OH}$ \\ Chardonnet, Christian, 23 \\ Chen, Jiayang, $1 Q$ \\ Chiodo, Nicola, 23 \\ Clark, Jeremy B., OT \\ Davidson, Nir, 1B \\ Dhayal, Suman, $1 \mathrm{C}$ \\ Digonnet, Michel J. F., OE, 1P \\ Dolfi, D., 1S, IT \\ Eger, David, 1B \\ Fallon, A., $1 Y$ \\ Fini, Lorenzo, $\mathrm{OH}$ \\ Firstenberg, Ofer, 1B \\ Franke-Arnold, Sonja, OD \\ Gibson, Graham, OD \\ Giraud-Carrier, Matthieu, 03 \\ Glasser, Ryan T., OT \\ Glorieux, Quentin, OT \\ Hawkins, Aaron R., 03 \\ Huang, Anping, $1 Q$ \\ Huignard, J. P., 1S, 1T \\ Ignesti, Emilio, $\mathrm{OH}$ \\ Jin, Junjie, 1Q \\ Jones, Kevin M., OT \\ Khripunov, Sergey, OA \\ Kobtsev, Sergey, OA \\ Kotlicki, Omer, OG \\ Kumar, Ranjeet, OR \\ Leonard, R. H., IY \\ Lett, Paul D., OT \\ Li, Tian, OT \\ Lin, Jian, $1 Q$ \\ Liu, Jinmei, OJ \\ Lopez, Olivier, 23 \\ Molin, S., 1S, $1 T$ \\ Mookherjea, Shayan, OR \\ Narum, Paul, OD \\ Padgett, Miles J., OD \\ Peigné, A., 1S, $1 T$ \\ Pottie, Paul-Eric, 23
}

\author{
Qin, Minglei, 0J \\ Quintin, Nicolas, 23 \\ Radnatarov, Daba, OA \\ Residori, S., 1S, $1 T$ \\ Rostovtsev, Yuri V., 1C \\ Sackett, C. A., $1 Y$ \\ Santarelli, Giorgio, 23 \\ Savanier, Marc, OR \\ Schever, Jacob, 0G, 00 \\ Schmidt, Holger, 03 \\ Schneider, Thomas, 22 \\ Shahriar, Selim, 00 \\ Shi, Zhimin, OD \\ Skolianos, George, OE \\ Smartsev, Slava, 1B \\ Stefani, Fabio, 23 \\ Tommasi, Federico, $\mathrm{OH}$ \\ Vigneron, Pierre-Baptiste, IP \\ Vogl, Ulrich, OT \\ Wang, Tantan, OJ \\ Wiotte, Fabrice, 23 \\ Wisniewski-Barker, Emma, OD \\ Xiao, Zhisong, $1 Q$ \\ Zamani Aghaie, Kiarash, 1P \\ Zhan, Li, OJ \\ Zhang, Hao, $1 Q$ \\ Zhang, Liang, OJ \\ Zhao, Long, 1Q
}


Proc. of SPIE Vol. $9378937801-6$

Downloaded From: https://www.spiedigitallibrary.org/conference-proceedings-of-spie on 25 Apr 2023 Terms of Use: https://www.spiedigitallibrary.org/terms-of-use 


\section{Conference Committee}

Symposium Chairs

David L. Andrews, University of East Anglia (United Kingdom)

Alexei L. Glebov, OptiGrate Corporation (United States)

Symposium Co-chairs

Jean-Emmanuel Broquin, IMEP-LAHC (France)

Shibin Jiang, AdValue Photonics, Inc. (United States)

Program Track Chair

Zameer U. Hasan, Temple University (United States)

Conference Chairs

Selim M. Shahriar, Northwestern University (United States)

Jacob Scheuer, Tel Aviv University (Israel)

Conference Program Committee

Tony Abi-Salloum, Widener University (United States)

Shanhui Fan, Stanford University (United States)

Daniel Joseph Gauthier, Duke University (United States)

Kohzo Hakuta, The University of Electro-Communications (Japan)

Ortwin Hess, Imperial College London (United Kingdom)

John C. Howell, University of Rochester (United States)

Jacob B. Khurgin, Johns Hopkins University (United States)

Uriel Levy, The Hebrew University of Jerusalem (Israel)

Frank A. Narducci, Naval Air Systems Command (United States)

Irina Novikova, The College of William \& Mary (United States)

Gour S. Pati, Delaware State University (United States)

Stefania Residori, Institut Non Linéaire de Nice Sophia Antipolis

(France)

Yuri Rostovtsev, University of North Texas (United States)

David D. Smith, NASA Marshall Space Flight Center (United States)

Yanhong Xiao, Fudan University (China)

Session Chairs

1 Slow Light: Waveguides and Resonators

Gour S. Pati, Delaware State University (United States) 
2 Precision Metrology: CPT-based Clocks and Cooled Molecular Ions Yannick Dumeige, Ecole Nationale Supérieure des Sciences

Appliquées et de Technologie (France)

3 Slow Light: Optimization and Application of Delay

Jacob Scheuer, Tel Aviv University (Israel)

4 Fast Light: Generation, Application, and Comparison with Slow Light

David D. Smith, NASA Marshall Space Flight Center (United States)

5 Precision Metrology Using Fast Light: Gyroscopy and Gravitational Wave Detection

Robert W. Boyd, University of Ottawa (Canada)

6 Slow Light: Quantum Information

Eugeniy E. Mikhailov, The College of William \& Mary (United States)

7 Precision Metrology: Spin Squeezing, Optical Squeezing, and Photon Correlation Interferometry

Elizabeth Donley, National Institute of Standards and Technology (United States)

8 Slow Light: Non-Linear Optics and Photon Drag

John C. Howell, University of Rochester (United States)

9 Precision Metrology: Sensing with NV Diamond Color Centers

Yanhong Xiao, Fudan University (China)

10 Slow Light: Novel Effects and New Directions

Susanne F. Yelin, University of Connecticut (United States)

11 Slow Light: New Platforms and Systems

Jacob B. Khurgin, Johns Hopkins University (United States)

12 Slow Light: Plasmonics and Metamaterials

Jesper Moerk, Technical University of Denmark (Denmark)

13 Precision Metrology: Coupled Resonator Gyroscopes and Other Sensors

Uriel Levy, The Hebrew University of Jerusalem (Israel)

14 Precision Metrology: Atomic Interferometry

Selim M. Shahriar, Northwestern University (United States)

15 Precision Metrology: Optical Clock and Frequency Combs Charles Sackett, University of Virginia (United States) 
16 Precision Metrology: Matter Wave Clock, Collective State Clock, and Other Developments

John H. Burke, Air Force Research Laboratory (United States)

Proc. of SPIE Vol. $9378937801-9$

Downloaded From: https://www.spiedigitallibrary.org/conference-proceedings-of-spie on 25 Apr 2023 Terms of Use: https://www.spiedigitallibrary.org/terms-of-use 
Proc. of SPIE Vol. $9378937801-10$

Downloaded From: https://www.spiedigitallibrary.org/conference-proceedings-of-spie on 25 Apr 2023 Terms of Use: https://www.spiedigitallibrary.org/terms-of-use 